\title{
GLIADIN ANALYSIS BY REVERSED-PHASE HIGH PERFORMANCE LIQUID CHROMATOGRAPHY
}

Vesna S. Gojković Cvjetković ${ }^{\star *}$, Radoslav D. Grujić², Željka R. Marjanović-Balaban², Ljiljana P. Stanojević ${ }^{4}$, Jelena S. Stanojević ${ }^{4}$, Milorad D. Cakić ${ }^{4}$

(ORIGINAL SCIENTIFIC PAPER) UDC 633.11:547.962.7:543.544

${ }^{1}$ University of East Sarajevo, Faculty of Tecnology Zvornik, Bosnia and Herzegovina

${ }^{2}$ State High School of Medical Science, Prijedor, Bosnia and Herzegovina

${ }^{3}$ University of Banja Luka, Faculty of Forestry Banja Luka, Bosnia and Herzegovina

${ }^{4}$ University of Niš, Faculty of Technology, Leskovac, Serbia

In order to develop a method for rapid, efficient and accurate detection and quantitative determination of gliadin proteins from wheat flour, the usage of different solvents and different separation conditions were investigated by reversed-phase high performance liquid chromatography (RP-HPLC). After albumin and globulins were removed from wheat flour $(100 \mathrm{mg})$ with a salt solution, the gliadin extraction was achieved with ethanol, 1-propanol and isopropanol (50\% v/v, 60\% v/v and $70 \% \mathrm{v} / \mathrm{v}$ each). Then, the glutenin fractions were extracted using nitrogen and $50 \%$ $(\mathrm{v} / \mathrm{v})$ aqueous solution of 1 -propanol containing Tris- $\mathrm{HCl}\left(0.05 \mathrm{~mol} / \mathrm{dm}^{3}, \mathrm{pH}=7.5\right)$ at $60{ }^{\circ} \mathrm{C}$, urea $\left(2 \mathrm{~mol} / \mathrm{dm}^{3}\right)$ and dithioerythritol $(1 \%)$. The separation and quantitative gliadin determination were carried out by RP-HPLC chromatography on C3 column maintained at different temperatures: $40^{\circ} \mathrm{C}, 45^{\circ} \mathrm{C}$ and $50^{\circ} \mathrm{C}$. In order to determine the absolute amounts of the protein type, gliadin protein standard was used. The obtained results in terms of repeatability, linearity and accuracy showed that RPHPLC chromatography could be used as a fast, relatively simple and reliable way to quantify all types of gluten proteins in wheat flour and can be applied to assess the quality of cereals as raw materials or in cereal products.
Keywords: gliadins, gliadin protein standard, C3 RP-HPLC column

\section{Introduction}

Gluten represents a protein fraction of wheat, rye and barley and types of cereals obtained from their crossbreeding, which is non-soluble in water and in $0.5 \mathrm{M} \mathrm{NaCl}$ solution [1]. Based on their solubility in an aqueous alcohol, gluten proteins are divided into two main fractions: gliadins and glutenins. Gliadins are monomeric proteins with molecular weight ranging between 28,000 Da and 55,000 Da. Based on their primary structure, gliadins are divided into several fractions: $\alpha+\beta, \gamma, \omega 5$ and $\omega 1,2$ [2]. Protein molecules of a glutenin fraction are chains that are interconnected by disulfide bonds. The molecular weight of the protein from glutenin fraction ranges from 500,000 to 10 million Da. Based on the primary structure glutenin subunits are divided into glutenin with high molecular weight (HMW) whose molecular weight ranges from 67,000 to $88,000 \mathrm{Da}$ and glutenin with low molecular weight (LMW) whose molecular weight is between 32,000 Da and 35,000 Da [2].

Besides their satisfying nutritional needs, some of the cereal proteins may have a negative effect on human health. They can cause intolerance to gluten and allergic reactions, known as IgE-mediated allergy or celiac disease, in a number of people. Celiac disease is a serious autoimmune disorder, which occurs after the intake of gluten into the body [3]. It is characterized by the inflammatio and damage of the small intestine epithelia and reduced absorption of certain nutrients such as: iron, calcium, vitamin $A, D, E, K$ and folate [4]. The main factors in the development of this disease are gliadins from gluten, certain genes and the immune system of individuals [5]. According to Grace-Farfaglia study [6], celiac disease occurs in genetically predisposed individuals, representing about $1.0 \%$ of the population in Europe and in the United States. Aziz et al. [7] estimate that one in five people in the world avoids gluten-containing foods. Gluten-free nutrition is the only therapy for people who suffer from celiac disease [8].

Wheat-dependent anaphylaxis (WDEIA) is a type of wheat allergy. It occurs after the intake of wheat products into the body [9]. It is estimated that $0.1 \%-3.0 \%$ of people in Europe are allergic to wheat, while in rural mountainous areas of Japan this percent reaches $0.21 \%$ [10]. Some experts $[9,11,12]$ are of the opinion that omega-5 gliadins are pathogens (allergens) of wheat-dependent anaphylaxis.

The most commonly used methods for gluten detection in food are: isoelectric focusing (IEF), sodium dodecyl sulphate polyacrylamide gel electrophoresis (SDS-PAGE), reversed-phase high pressure liquid chromatography (RP-HPLC), exclusion chromatography (SE-HPLC), highpressure zone electrophoresis (HPCE), coupled liquid

\footnotetext{
** Author address: Vesna Gojković Cvjetković, University of East Sarajevo, Faculty of Tecnology Zvornik,

75400 Zvornik, Karakaj 34a, Bosnia and Herzegovina

E-mail: vesna.gojkovic@yahoo.com

The manuscript received: October, 23, 2019.

Paper accepted: November, 18, 2019.
} 
chromatography-mass spectrometry (LC-MS/MS), enzyme-immunochemical method (ELISA), chain reaction polymerase (PCR). Development of new methods for gluten proteins analysis includes immunosensors and microchips [5].

The usage of C3 column significantly reduces the analysis duration, and the obtained chromatograms are almost identical to those obtained on C8 and C18 columns. In this paper, researchers are trying to give their contribution to the development of a new method for identifying and quantifying the gliadin fraction as a potential food allergen. It was decided to use RP-HPLC chromatography for the analysis of gliadins present in food. Different extraction conditions (different solvents and their concentrations) and proteins separation conditions (different column temperatures) were tested in order to achieve the complete proteins separation, their easier identification and determination of their content in food.

\section{Experimental}

Material and methods

Gluten proteins - gliadins were analyzed in wheat flour type 500 purchased in convenience stores. Ethanol, 1-propanol and isopropanol of various concentrations $(50 \%$, $60 \%$ and $70 \% \mathrm{v} / \mathrm{v}$ ) were used as extraction solvents. Sodium chloride $(\mathrm{NaCl})$ and potassium dihydrogen phosphate (KH2PO4) were purchased from Lach-Ner (Czech Republic). Trifluoroacetic acid (TFA) was purchased from Acros (France) and acetonitrile (ACN) of HPLC purity was purchased from Biosolve Chimie (France). Gliadin from wheat gluten (MP Biomedicals, LLC) was used as external standard.

\section{Gliadin extraction from wheat flour}

Gliadins were extracted with $100 \mathrm{mg}$ of wheat flour according to the modified Wieser et al. [13] method. First, albumin and globulin were extracted twice with $1 \mathrm{~cm}^{3}$ of 0.4 $\mathrm{mol} / \mathrm{dm}^{3} \mathrm{NaCl}$ solution with the addition of $0.067 \mathrm{~mol} / \mathrm{dm}^{3}$ of $\mathrm{KH}_{2} \mathrm{PO}_{4}$ solution at $\mathrm{pH}=7.6$, at room temperature $\left(20^{\circ} \mathrm{C}\right)$. After albumin and globulin supernatant removal, gliadins were extracted three times with $0.5 \mathrm{~cm}^{3}$ of solvent (ethanol, 1-propanol, isopropanol) at room temperature. Each time after the solvent addition, homogenization of the sample on the vortex (Advanced Vortex Mixer ZX3, Velp scientifica) was carried out for 2 minutes. Thereafter, stirring was continued on a magnetic stirrer (Velp scientifica) for 10 minutes. After homogenization was completed, centrifugation (Hettich zentrifugen, rotina $380 \mathrm{R}$ ) of the samples was performed for 15 minutes (albumin and globulin) and 20 minutes (gliadins) at 7,000 rpm. The supernatants were supplemented to $2.0 \mathrm{~cm}^{3}$ with a suitable extractant solvent. Immediately before the analysis the sample was filtered through a $0.45 \mu \mathrm{m}$ membrane filter (RC syringe filters, Filtratech, France).
RP-HPLC chromatography

RP-HPLC chromatography was carried out on the HPLC Agilent Technologies 1260 Infinity apparatus. Gliadin proteins ( $\omega 5, \omega 1,2, \alpha+\beta$ and $\gamma$ ) separation was performed on the Zorbax 300 SB-C3 (Agilent Technologies) column, size $4.6 \times 150 \mathrm{~mm}$, particle size $5 \mu \mathrm{m}$, maintained at a temperature of 40,45 and $50^{\circ} \mathrm{C}$. Two mobile phases were used: deionized water (eluent $\mathrm{A}$ ) and $0.1 \%$ trifluoroacetic acid (TFA) in acetonitrile (ACN) of HPLC purity (eluent B). Gliadins were separated by gradient elution adjusted as follows: $0-8.5 \min 30-40 \%$ B; $8.5-10 \min 40 \%$ B; $10-12 \min$ $40-43 \%$ B; $12-20$ min $43-55 \%$ B; $20-25 \mathrm{~min} 30 \%$ B at $1 \mathrm{~cm}^{3 /}$ min flow. The injection volume was $70 \mu \mathrm{l}$. The detection wavelength was $210 \mathrm{~nm}$.

\section{Results and discussion}

During the gliadin analysis in wheat flour samples, a gliadin solution in ethanol was used as an external standard, having the concentration of $4.00 \mathrm{mg}$ in $1 \mathrm{~cm}^{3}$ of $70 \%$ $(\mathrm{v} / \mathrm{v})$ ethanol (Figure 1). In order to assess the quality of measurement, Agilent ChemStation software was used to calculate the average value and standard deviation of the retention time as well as the relative concentration for the four proteins from different fractions of gliadin standard. The average retention time for the first selected protein was $4.16 \mathrm{~min}$ and its relative concentration was $3.17 \%$, for the second protein $7.69 \mathrm{~min}$ and $17.44 \%$, for the third protein $8.35 \mathrm{~min}$ and $26.23 \%$ and for the fourth protein $10.95 \mathrm{~min}$ and $17.17 \%$ (Figure 1).

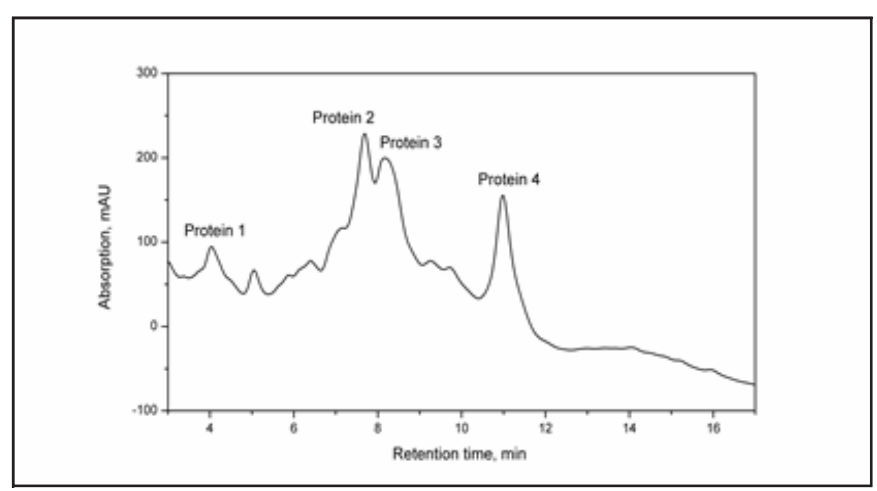

Figure 1. RP-HPLC chromatogram of gliadin standard dissolved in $70 \%(\mathrm{v} / \mathrm{v})$ ethanol

Identification and quantification of gliadin proteins standard

Identification of gliadin proteins was performed according to the method described by Wieser et al. [13]. Figure 2 shows RP-HPLC chromatogram of gliadins extracted with $70 \%(\mathrm{v} / \mathrm{v})$ ethanol and separated at a column temperature of $45^{\circ} \mathrm{C}$. The highest polarity, i.e. the shortest retention time was recorded in $\omega 5$ gliadins (from 3.0 to $5.5 \mathrm{~min}$ ), followed by $\omega 1,2$ (5.5-8.0 $\mathrm{min}$ ), $\alpha+\beta$ (8.0 to $12.5 \mathrm{~min}$ ) and y gliadins (12.5-16.0 $\mathrm{min}$ ) - Figure 2. 


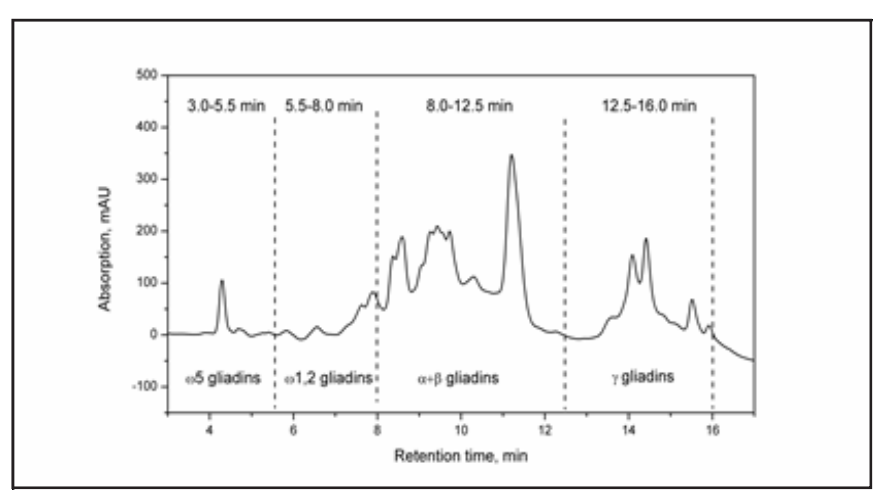

Figure 2. RP-HPLC chromatogram of various gliadin fractions extracted from wheat flour using $70 \%(\mathrm{v} / \mathrm{v})$ ethanol

Repeatability of the method

Figure 3 shows the repeatability of the results based on the obtained RP-HPLC chromatograms of gliadins. $70 \%(\mathrm{v} / \mathrm{v})$ ethanol was used for the extraction, and the separation was carried out at a column temperature of $45^{\circ} \mathrm{C}$. Based on the obtained chromatograms, it can be seen that the repeatability of the results is quite good and chromatograms obtained during 6 repetitions are approximately identical.

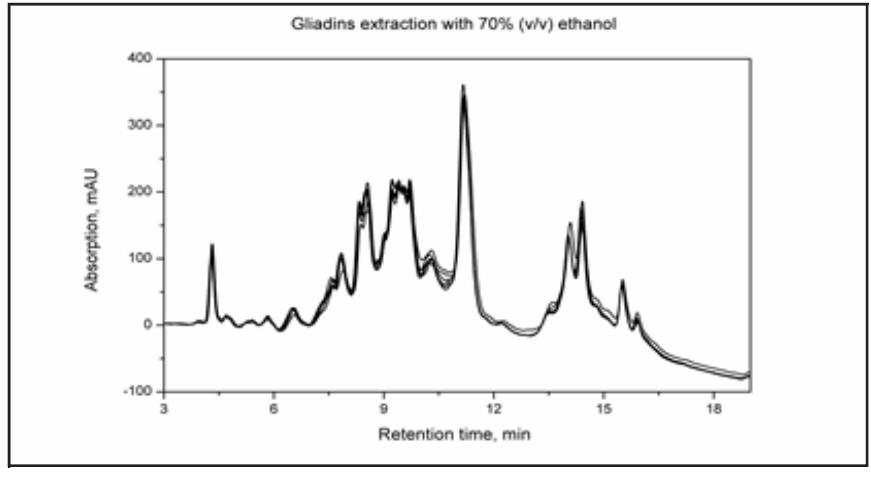

Figure 3. Repeatability of the result ( 6 repetitions) obtained by RP-HPLC chromatography of gliadins at optimum extraction and chromatography conditions

Figure 4 shows RP-HPLC chromatograms of gliadins obtained using different concentrations $(50 \%, 60 \%$ and $70 \% \mathrm{v} / \mathrm{v}$ ) of ethanol, as extraction solvent. The chromatography was performed at different column temperatures $\left(40,45\right.$ and $\left.50{ }^{\circ} \mathrm{C}\right)$. The obtained chromatograms show that the best separation and the highest number of proteins were identified by extraction with $70 \%(\mathrm{v} / \mathrm{v})$ ethanol, at column temperature of $45^{\circ} \mathrm{C}$.
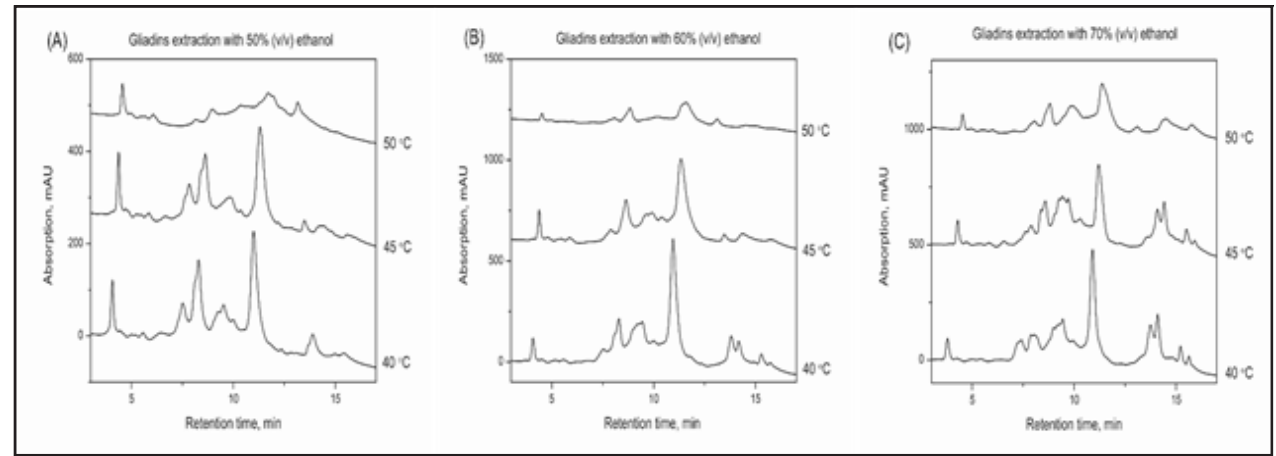

Figure 4. RP-HPLC chromatograms of gliadins isolated from wheat flour by extraction with ethanol (A - 50\% ethanol, B - 60\% ethanol, C - 70\% ethanol) and separated during 16.0 min at different column temperatures $\left(40,45\right.$ and $\left.50^{\circ} \mathrm{C}\right)$

Identification and quantification of gliadin proteins

Table 1 shows the total number (TP) and Table 2 the relative concentration $(R C)$ of identified gliadin proteins (average value - Xav and standard deviation - SD) and their fractions, depending on the solvent used, solvent concentration, and the applied column temperature in RP-HPLC chromatography. Based on the protein retention time on the chromatogram and in accordance with Wieser et al. [13] method, protein counts were made within each protein fraction (Table 1), and the relative concentration of each protein was calculated in relation to the total number of proteins (Table 2).

\section{Gliadins extraction with ethanol}

The obtained results showed that the highest number of identified proteins, using ethanol as a solvent, and maintaining column temperature at $40{ }^{\circ} \mathrm{C}$ during the chromatographic separation, was in the case of extraction with $60 \%(\mathrm{v} / \mathrm{v})$ ethanol yielding 28 proteins (calculated as the average value of 6 repetitions). Maintaining the column temperature at 45 and $50^{\circ} \mathrm{C}$, the highest number of identified proteins was extracted with $70 \%(\mathrm{v} / \mathrm{v})$ ethanol yielding 29 and 26 proteins, respectively (Table 1 ). Thus, by comparing the results obtained using three different concentrations of extraction solvent (ethanol) and three different column temperatures for chromatography, it can be concluded that the highest number of identified proteins was extracted with $70 \%(\mathrm{v} / \mathrm{v})$ ethanol, at a column temperature of $45^{\circ} \mathrm{C}$. The total number of identified proteins (29) obtained by extraction under optimal conditions (ethanol concentration of $70 \% \mathrm{v} / \mathrm{v}$ and column temperature of $45^{\circ} \mathrm{C}$ ) comprised of: $\omega 5$ gliadins - 5 proteins (standard deviation SD is 0.00 ), $\omega 1,2$ gliadins -5 proteins $(S D=0.00), \alpha+\beta$ gliadins -8 proteins $(S D=0.00)$ and $y$ gliadins - 11 proteins $(S D=0.00)$ - Table 1 . The relative concentration of proteins obtained by extraction with $70 \%$ 
(v/v) ethanol was: $\omega 5$ gliadins $3.56 \%$ ( $S D=0.23)$, $\omega 1,2$ gliadins $9.80 \%$, $(S D=0.54), \alpha+\beta$ gliadins $44.19 \%(S D=1.16)$ and $y$ gliadins $42.44 \%(S D=1.53)$ - Table 2.

Horvat et al. [14] identified a total of 28 proteins consisting of 1-3 proteins within $\omega 5$ gliadins, 3-6 proteins within $\omega 1,2,8-10$ proteins within $\alpha$ and 6-9 proteins within $Y$ gliadins fractions after separating the gluten proteins by RP-HPLC chromatography (C18 column, column temperature $50{ }^{\circ} \mathrm{C}$, separation time of 30 minutes). Bietz et al. [15] used C18 columns, and 70\% (v/v) ethanol and $55 \%(\mathrm{v} / \mathrm{v})$ isopropanol as extraction solvents for gliadin extraction by optimizing conditions for the gliadin extraction by HPLC method. After chromatographic separation (the separation time for gliadin was 65 minutes), almost identical chromatograms to the ones presented in this paper were obtained. Wieser [16], used RP-HPLC chromatography (solvent: $60 \%$ v/v ethanol, C8 column, separation time: 40 minutes), for analyzing the solubility of gliadin proteins from wheat flour and bread. According to his results, due to the heat influence during bread baking, the solubility of gliadin extracted from the bread is less than the solubility of these proteins extracted with $60 \%$ $(v / v)$ ethanol from bread.

\section{Gliadin extraction with 1-propanol and isopropanol}

For the gliadin extraction from wheat flour samples, 1-propanol was also used in three concentrations $(50 \%$, $60 \%$ and $70 \% \mathrm{v} / \mathrm{v})$. After extraction with $50 \%(\mathrm{v} / \mathrm{v}) 1$-propanol and chromatographic separation, 25 (at a column temperature of $45^{\circ} \mathrm{C}$ ) and 28 (at a column temperature of $40{ }^{\circ} \mathrm{C}$ ) peaks, representing gliadin proteins were detected. When the column temperature was maintained at $45{ }^{\circ} \mathrm{C}$ during the separation, the number of well separated proteins peaks extracted with $60 \%(\mathrm{v} / \mathrm{v})$ and $70 \%$ (v/v) 1-propanol from flour samples was 28 and 25, respectively. By protein extraction with $60 \%$ (v/v) 1-propanol and their separation at column temperature of $50{ }^{\circ} \mathrm{C}, 21$ proteins were obtained (Table 1 ). The results obtained indicate that the best protein extraction efficiency (regarding the total number of proteins) was achieved when $50 \%(\mathrm{v} / \mathrm{v})$ 1-propanol was used as a solvent. The proportion of particular fractions in the total number of detected proteins (28) separated after extraction with the optimal solvent ( $50 \% \mathrm{v} / \mathrm{v} 1$-propanol), under the optimal separation conditions (column $\mathrm{C} 3$, column temperature $40{ }^{\circ} \mathrm{C}$ ) comprised of: $\omega 5$ gliadins -4 proteins $(2.40 \%), \omega 1,2$ gliadins -6 proteins $(5.23 \%), \alpha+\beta$ gliadins -9 proteins $(34.87 \%)$ and $y$ gliadins - 9 proteins $(57.51 \%)$ - Tables 1 and 2.

During the study of isopropanol concentration (50\%, $60 \%$ and $70 \% \mathrm{v} / \mathrm{v}$ ) effect on the effectiveness of gliadin proteins extraction, the best results were obtained after extraction with $60 \%(\mathrm{v} / \mathrm{v})$ isopropanol solution (Table 1). Under column temperature of $45^{\circ} \mathrm{C} 27$ well-separated protein peaks were determined. The proportion of particular fractions in the total number of detected proteins (27) comprised of: $\omega 5$ gliadin - 6 proteins $(2.55 \%), \omega 1,2$ gliadins -5 proteins $(7.56 \%), \alpha+\beta$ gliadins -8 proteins
(39.54\%) and y gliadins - 8 proteins (50.35\%) - Tables 1 and 2.

Wieser [17] used RP-HPLC chromatography (C8 column) to analyze gluten proteins from different types of wheat. Based on the retention time of particular fractions, he divided gliadins into 4 fractions: a gliadins (retention time from 24-33 min, relative concentration 28.00-45.30\%), y gliadins (retention time 33-37 min and relative concentration $19.80-31.30 \%$ ) and $\omega 1,2 / \omega 5$ gliadins (retention time 11-24 min and relative concentration 6.40$14.80 \%)$. The remaining peaks on chromatograms represented glutenins with low molecular weight (10.00 to $25.10 \%$ ) and glutenins with high molecular weight (from 2.60 to $9.30 \%$ ). Scherf [18] analyzed gliadin and glutenin proteins from wheat starch using the ELISA method and RP-HPLC chromatography on a C18 column at a column temperature of $60{ }^{\circ} \mathrm{C}$. Protein separation analysis lasted for 25 minutes.

The influence of solvent concentration used

Studying the effects of solvent type and its concentration for the gliadin extraction from wheat flour samples, we obtained the best results (in the terms of the separated or detected peak proteins number) using $70 \%(\mathrm{v} / \mathrm{v})$ ethanol (29 proteins), followed by $50 \%$ (v/v) 1-propanol (28 proteins) and $60 \%(\mathrm{v} / \mathrm{v})$ isopropanol (27 proteins) Table 1. The obtained results are in accordance with previously published results $[14,15]$.

The number of identified $\omega 5$ fraction proteins under optimal extraction and separation conditions, was 5 (solvent: $70 \% \mathrm{v} / \mathrm{v}$ ethanol, column temperature: $45^{\circ} \mathrm{C}$ ), $4\left(50 \%\right.$ v/v 1-propanol and column temperature $\left.40{ }^{\circ} \mathrm{C}\right)$ and $6(60 \% \mathrm{v} / \mathrm{v}$ isopropanol and column temperature of $45^{\circ} \mathrm{C}$ ). Under optimal analysis conditions within the $\omega 1,2$ gliadins, the number of detected proteins was: 5 proteins ( $70 \% \mathrm{v} / \mathrm{v}$ ethanol and column temperature $45^{\circ} \mathrm{C}$ ), 6 proteins $\left(50 \%\right.$ v/v 1-propanol, column temperature $40{ }^{\circ} \mathrm{C}$ ) and 5 proteins $(60 \% \mathrm{v} / \mathrm{v}$ isopropanol and column temperature $45^{\circ} \mathrm{C}$ ) (Table 1). The number of proteins within $\alpha+\beta$ and $\gamma$-gliadins fractions separated under optimal conditions $\left(70 \% \mathrm{v} / \mathrm{v}\right.$ ethanol and column temperature $\left.45^{\circ} \mathrm{C}\right)$ was 8 and 11 proteins, respectively. Using $50 \%(\mathrm{v} / \mathrm{v})$ 1-propanol and column temperature of $40{ }^{\circ} \mathrm{C}, 9$ proteins within $\alpha+\beta$ and 9 proteins within $\gamma$-gliadins fractions were obtained and finally, $8(\alpha+\beta)$ and 8 ( $\gamma$-gliadins) proteins were obtained using $60 \%(\mathrm{v} / \mathrm{v})$ isopropanol and column temperature of $45^{\circ} \mathrm{C}$ (Table 1).

The best results in the identification of proteins were achieved when the gliadin proteins were extracted with $70 \%(\mathrm{v} / \mathrm{v})$ ethanol, and separation performed at column temperature of $45{ }^{\circ} \mathrm{C}$. In this case, the relative concentrations of individual fractions were as follows: $\alpha+\beta$ (44.19\%), y (42.44\%), $\omega 1,2(9.80 \%)$ and $\omega 5(3.56 \%)$ gliadins, which is in accordance with the results obtained by Wieser [17]. In the case of gliadin proteins extraction with $50 \%(\mathrm{v} / \mathrm{v})$ 1-propanol and at a column temperature of $40{ }^{\circ} \mathrm{C}$, the relative concentrations of $\alpha+\beta$ gliadin fractions were $34.87 \%$, y gliadin $-57.51 \%$, $\omega 1,2-5.23 \%$, 
$\omega 5-2.40 \%$. After the extraction of gliadin proteins with $60 \%(\mathrm{v} / \mathrm{v})$ isopropanol and at a column temperature of $45{ }^{\circ} \mathrm{C}$, the relative concentrations were: $\alpha+\beta-39.54 \%$, y - 50.35\%, w1,2-7.56\%, $\omega 5-2.55 \%$ (Table 2).

Table 1.The total number of proteins and number of proteins separated and detected by fractions

\begin{tabular}{|c|c|c|c|c|c|c|c|c|c|c|c|c|c|c|c|}
\hline & \multicolumn{15}{|c|}{ Column temperature $\left({ }^{\circ} \mathrm{C}\right)$} \\
\hline & \multicolumn{5}{|c|}{40} & \multicolumn{5}{|c|}{45} & \multicolumn{5}{|c|}{50} \\
\hline \multicolumn{16}{|c|}{ Protein fractions } \\
\hline & $\mathrm{TP}$ & $\omega 5$ & $\omega 1.2$ & $\alpha+\beta$ & Y & $\mathrm{TP}$ & $\omega 5$ & $\omega 1.2$ & $\alpha+\beta$ & $\mathrm{Y}$ & TP & $\omega 5$ & $\omega 1.2$ & $\alpha+\beta$ & $\mathrm{Y}$ \\
\hline Xav & 26 & 5 & 5 & 9 & 7 & 27 & 6 & 7 & 9 & 5 & 24 & 4 & 6 & 8 & 6 \\
\hline $\mathrm{SD}$ & 0.47 & 0.74 & 0.89 & 0.82 & 0.76 & 0.76 & 0.74 & 0.74 & 0.74 & 0.47 & 0.74 & 0.47 & 0.50 & 0.47 & 0.89 \\
\hline Xav & 28 & 6 & 3 & 12 & 7 & 22 & 6 & 3 & 6 & 7 & 24 & 7 & 3 & 8 & 7 \\
\hline SD & 1.15 & 0.74 & 0.82 & 0.37 & 1.07 & 1.25 & 0.47 & 0.58 & 0.37 & 1.60 & 0.69 & 0.50 & 0.00 & 0.47 & 0.50 \\
\hline Xav & 26 & 4 & 4 & 11 & 7 & 29 & 5 & 5 & 11 & 8 & 26 & 4 & 6 & 10 & 6 \\
\hline SD & 0.94 & 0.37 & 0.37 & 0.94 & 0.00 & 0.00 & 0.00 & 0.00 & 0.00 & 0.00 & 0.69 & 0.37 & 0.90 & 0.00 & 0.00 \\
\hline Xav & 28 & 4 & 6 & 9 & 9 & 25 & 4 & 5 & 8 & 8 & 22 & 5 & 5 & 6 & 6 \\
\hline SD & 1.21 & 0.47 & 0.94 & 0.47 & 0.74 & 1.10 & 0.37 & 0.76 & 0.90 & 0.47 & 0.74 & 0.37 & 0.90 & 0.50 & 0.37 \\
\hline Xav & 23 & 3 & 4 & 10 & 6 & 26 & 5 & 5 & 9 & 8 & 21 & 5 & 2 & 8 & 6 \\
\hline SD & 1.07 & 0.37 & 0.37 & 0.37 & 0.76 & 0.58 & 0.00 & 0.47 & 0.82 & 0.37 & 0.74 & 0.00 & 0.37 & 0.00 & 0.76 \\
\hline Xav & 26 & 6 & 4 & 10 & 6 & 23 & 5 & 6 & 6 & 6 & 26 & 4 & 5 & 10 & 7 \\
\hline SD & 0.94 & 0.37 & 0.00 & 1.07 & 0.47 & 1.25 & 0.94 & 0.47 & 0.74 & 0.47 & 0.90 & 0.00 & 0.37 & 0.47 & 0.69 \\
\hline Xav & 26 & 3 & 6 & 9 & 8 & 26 & 5 & 5 & 10 & 6 & 26 & 3 & 7 & 10 & 6 \\
\hline SD & 1.53 & 0.37 & 0.50 & 0.76 & 0.37 & 0.47 & 0.47 & 0.69 & 0.37 & 0.00 & 1.21 & 0.37 & 1.10 & 0.00 & 0.69 \\
\hline Xav & 26 & 3 & 5 & 10 & 8 & 27 & 6 & 5 & 8 & 8 & 25 & 2 & 7 & 9 & 7 \\
\hline SD & 0.47 & 0.00 & 0.00 & 0.00 & 0.50 & 0.47 & 0.37 & 0.50 & 0.00 & 0.00 & 0.37 & 0.00 & 0.47 & 0.50 & 0.00 \\
\hline Xav & 22 & 2 & 5 & 9 & 6 & 26 & 6 & 5 & 8 & 7 & 26 & 4 & 5 & 9 & 8 \\
\hline SD & 0.82 & 0.00 & 0.37 & 0.69 & 0.94 & 0.00 & 0.00 & 0.00 & 0.00 & 0.00 & 0.50 & 0.00 & 0.47 & 0.00 & 0.37 \\
\hline
\end{tabular}

Table 2. The relative concentration of the total proteins and protein fractions

\begin{tabular}{|c|c|c|c|c|c|c|c|c|c|c|c|c|}
\hline \multicolumn{13}{|c|}{ Column temperature $\left({ }^{\circ} \mathrm{C}\right)$} \\
\hline \multicolumn{5}{|c|}{40} & \multicolumn{4}{|c|}{45} & \multicolumn{4}{|c|}{50} \\
\hline \multicolumn{13}{|c|}{ Protein fractions } \\
\hline & $\omega 5$ & $\omega 1,2$ & $\alpha+\beta$ & Y & $\omega 5$ & $\omega 1,2$ & $\alpha+\beta$ & $\mathrm{Y}$ & $\omega 5$ & $\omega 1,2$ & $\alpha+\beta$ & $\mathrm{r}$ \\
\hline Xav & 7.96 & 15.73 & 36.72 & 39.51 & 9.96 & 14.81 & 35.78 & 39.45 & 7.45 & 9.98 & 31.73 & 50.92 \\
\hline $\mathrm{SD}$ & 0.43 & 0.73 & 1.17 & 0.99 & 0.41 & 0.63 & 1.46 & 1.76 & 0.67 & 0.70 & 1.82 & 2.71 \\
\hline Xav & 4.33 & 5.97 & 52.14 & 37.39 & 4.61 & 6.71 & 52.03 & 36.64 & 3.77 & 6.68 & 56.12 & 33.33 \\
\hline SD & 0.66 & 0.53 & 1.72 & 1.35 & 0.49 & 1.33 & 2.08 & 1.47 & 0.36 & 0.65 & 0.63 & 0.63 \\
\hline Xav & 4.74 & 15.91 & 54.21 & 24.67 & 3.56 & 9.80 & 42.44 & 44.19 & 4.15 & 9.87 & 46.68 & 39.30 \\
\hline SD & 0.48 & 0.62 & 2.16 & 2.25 & 0.23 & 0.54 & 1.53 & 1.16 & 0.24 & 1.63 & 1.49 & 1.29 \\
\hline Xav & 2.40 & 5.23 & 57.51 & 34.87 & 2.35 & 5.03 & 55.13 & 37.49 & 3.71 & 5.27 & 57.61 & 33.08 \\
\hline SD & 0.11 & 0.82 & 1.83 & 2.01 & 0.27 & 0.94 & 2.59 & 3.42 & 0.13 & 0.99 & 5.29 & 4.08 \\
\hline Xav & 7.00 & 5.84 & 63.70 & 23.46 & 9.79 & 6.95 & 51.86 & 31.40 & 5.42 & 5.73 & 66.77 & 22.07 \\
\hline$S D$ & 0.85 & 0.92 & 2.23 & 1.85 & 0.69 & 0.34 & 0.88 & 1.15 & 0.67 & 0.33 & 1.21 & 0.60 \\
\hline Xav & 9.16 & 8.92 & 56.51 & 25.40 & 7.21 & 8.84 & 54.24 & 29.71 & 5.19 & 6.13 & 64.33 & 24.35 \\
\hline SD & 0.51 & 0.77 & 0.96 & 0.85 & 1.15 & 1.01 & 1.40 & 1.05 & 1.11 & 0.64 & 1.72 & 1.77 \\
\hline Xav & 2.31 & 6.64 & 33.60 & 54.48 & 2.21 & 7.97 & 41.71 & 48.07 & 2.21 & 6.89 & 39.02 & 51.88 \\
\hline$S D$ & 0.33 & 1.25 & 3.34 & 6.69 & 0.25 & 0.92 & 4.99 & 4.11 & 0.31 & 1.82 & 1.01 & 2.62 \\
\hline Xav & 2.94 & 7.63 & 29.60 & 53.40 & 2.55 & 7.56 & 39.54 & 50.35 & 2.45 & 7.08 & 35.83 & 54.81 \\
\hline SD & 0.26 & 0.55 & 0.66 & 9.30 & 0.17 & 1.84 & 1.04 & 1.14 & 0.26 & 0.51 & 1.21 & 1.24 \\
\hline Xav & 3.81 & 7.83 & 31.26 & 57.10 & 3.54 & 7.91 & 26.82 & 61.73 & 3.40 & 9.00 & 26.13 & 61.48 \\
\hline SD & 0.66 & 1.29 & 1.83 & 1.32 & 0.46 & 0.66 & 1.36 & 2.02 & 0.32 & 0.79 & 0.55 & 1.35 \\
\hline
\end{tabular}




\section{Conclusions}

The purpose of this paper was to find the optimal conditions for extraction and chromatographic separation of gliadin proteins from wheat. After analyzing a large number of different combinations of species and solvent concentration, $70 \%(\mathrm{v} / \mathrm{v})$ ethanol proved to be the best solvent for gliadin extraction. In this case, the highest number of peaks on the chromatogram was obtained, and the highest number of proteins (29) was detected after the separation of gliadin proteins. The optimum temperature for chromatography was $45^{\circ} \mathrm{C}$. The proteins extraction and separation by RP-HPLC on C3 silica gel column described in this paper enables a rapid and selective separation, accurate and rapid detection and quantitative determination of relative amounts of gliadin proteins and gluten derived from wheat flour. The method is sufficiently sensitive and could be applied for the analysis of very small sample quantities. It is very important to emphasize that this method provides the possibility to trace the presence of gliadin in wheat products, which is important for informing the consumers suffering from celiac disease and the consumers who have gliadin intolerance and allergic reactions to cereal products.

\section{Acknowledgements}

This work is a part of the research project Analysis gluten proteins holders of allergic reactions by high performance liquid chromatography, number 19/6-020/96123/18, financed by the Ministry of Science and Technology, Higher Education and Information Society Republic of Srpska and project TR 34012, financed by the Ministry of Education, Science and Technological Development of Republic of Serbia.

\section{References}

[1] Codex Alimentarius Commission, Codex Standard: Codex Standard for foods for special dietary use for persons intolerant to gluten, Revision 1, (2008) 118-1979.

[2] H. Wieser, Chemistry of gluten proteins, Food Microbiology, 24 (2007) 115-119.

[3] C. Cui, T. Basen, A.T. Philipp, J. Yusin, G. Krishnaswamy, Celiac disease and nonceliac gluten sensitivity, Annals of Allergy Asthma \& Immunology, 118 (2017) 389-393.

[4] S. Picascia, R. Mandile, R. Auricchio, R. Troncone, C. Gianfrani, Gliadin-specific T-cells mobilized in the peripheral blood of coeliac patients by short oral gluten challenge: clinical applications, Nutrients, 7 (2015) 1002010031.

[5] F. Malvano, D. Albanese, R. Pilloton, M. Di Matteo, A new label-free impedimetric aptasensor for gluten detection, Food Control, 79 (2017) 200-206.

[6] P. Grace-Farfaglia, Bones of contention: bone mineral density recovery in celiac disease-a systematic review, Nutrients, 7 (2015) 3347-3369.

[7] I. Aziz, M. Hadjivassiliou, D.S. Sanders, The spectrum of noncoeliac gluten sensitivity, Nature Reviews Gastroenterology \& Hepatology, 12 (2015) 516-526.
[8] K.A. Scherf, P. Koehler, H. Wieser, Gluten and wheat sensitivities - an overview, Journal of Cereal Science, 67 (2016) 2-11.

[9] E. Morita, K. Kunie, H. Matsuo, Food-dependent exerciseinduced anaphylaxis, Journal of Dermatological Science, 47 (2007) 109-117.

[10] B.I. Nwaru, L. Hickstein, S.S. Panesar, G. Roberts, A. Muraro, A. Sheikh, Prevalence of common food allergies in Europe: a systematic review and meta-analysis, Allergy, 69 (2014) 992-1007.

[11] H. Matsuo, E. Morita, A.S. Tatham, K. Morimoto, T. Horikawa, H. Osuna, Z. Ikezawa, S. Kaneko, K. Kohno, S. Dekio, Identification of the IgE-binding epitope in omega-5 gliadin, a major allergen in wheat dependent exerciseinduced anaphylaxis, Journal of Biological Chemistry, 279 (2004) 12135-12140.

[12] K. Palosuo, H. Alenius, E. Varjonen, N. Kalkkinen, T. Reunala, Rye gamma-70 and gamma-35 secalins and barley gamma-3 hordein cross-react with omega 5 gliadin, a major allergen in wheat-dependent, exercise induced anaphylaxis, Clinical and Experimental Allergy, 31 (2001) 466-473.

[13] H. Wieser, S. Antes, W. Seilmeier, Quantitative determination of gluten protein types in wheat flour by reverse-phase high performance liquid chromatography, Cereal Chemistry, 75 (1998) 644-650.

[14] D. Horvat, G. Drezner, G. Šimić, K. Dvojković, Determination of wheat storage proteins by RP-HPLC method, Poljoprivreda, 12 (2006) 42-47. In Croatian.

[15] J.A. Bietz, T. Burnouf, L.A. Cobb, J.S. Wall, Gliadin analysis by reversed-phase high performance liquid chromatography: optimization of extraction conditions, Cereal Chemistry, 61 (1984) 124-129.

[16] H. Wieser, Investigations on the extractability of gluten proteins from wheat bread in comparison with flour, Zeitschrift für Lebensmitteluntersuchung und -Forschung A, 207 (1998) 128-132.

[17] H. Wieser, Comparative investigations of gluten proteins from different wheat species, European Food Research and Technology, 211 (2000) 262-268.

[18] K.A. Scherf, Impact of the preparation procedure on gliadin, glutenin and gluten contents of wheat starches determined by RP-HPLC and ELISA, European Food Research and Technology, 242 (2016) 1837-1848 
Izvod

\section{ANALIZA PROTEINA GLIJADINA VISOKO-PRITISNOM TEČNOM HROMATOGRAFIJOM}

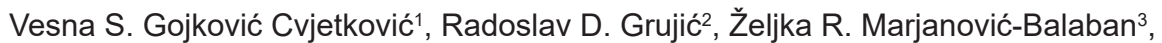
Ljiljana P. Stanojević ${ }^{4}$, Jelena S. Stanojević ${ }^{4}$, Milorad D. Cakić ${ }^{4}$

1Univerzitet u Istočnom Sarajevu, Tehnološki fakultet, Zvornik, Bosna i Hercegovina

${ }^{2}$ Visoka medicinska škola, Prijedor, Bosna i Hercegovina

3 Univerzitet u Banja Luci, Šumarski fakultet, Banja Luka, Bosna i Hercegovina

4 Univerzitet u Nišu, Tehnološki fakultet, Leskovac, Srbija

U cilju razvoja metode za brzu, efikasnu i tačnu detekciju i kvantitativno određivanje različitih proteina glijadina iz pšenice ispitivana je primena različitih rastvarača i različitih uslova razdvajanja pomoću visoko-pritisne tečne hromatografije (HPLC). Nakon odvajanja albumina i globulina iz pšeničnog brašna (100 mg) sa rastvorima soli $(2 \times 1,0 \mathrm{ml})$, ekstrakcija glijadina je vršena sa 40\%, 50\%, 60\% и $70 \%$ (v/v) vodenim rastvorom etanola, izopropanola, 1-propanola $(3 \times 0,5 \mathrm{ml})$. Nakon toga, frakcije glutenina su ekstrahovane u struji azota i na $60{ }^{\circ} \mathrm{C}$ ca $50 \%(\mathrm{v} / \mathrm{v})$ vodenim rastvorom 1-propanola koji sadrži Tris- $\mathrm{HCl}(0,05 \mathrm{~mol} / \mathrm{L}, \mathrm{pH} 7,5)$, urea $(2 \mathrm{~mol} / \mathrm{L})$ и ditioeritritol (1\%). Razdvajanje i kvantitativno određivanje glijadina je vršeno pomoću HPLC sa reverznom fazom na C3 silika gelu kod različitih temperatura kolone 40 , 45 i $50^{\circ} \mathrm{C}$. S ciljem dobijanja apsolutne količine proteina, korišćen je standard proteina glijadina. Dobijeni rezultati u pogledu ponovljivosti, linearnosti i tačnosti pokazuju da se visoko-pritisna tečna hromatografija obrnutih faza može koristiti kao brz, relativno jednostavan i pouzdan način kvantifikovanja svih vrsta glutenskih proteina u pšeničnom brašnu i može se primeniti na ocenu kvaliteta žitarica kao sirovine ili u proizvodima od žitarica.
(ORIGINALNI NAUČNI RAD) UDK 633.11:547.962.7:543.544

Ključne reči: alijadini, alijadin protein standard, C3 RP-HPLC kolona 